\title{
Stunde Null and the 'construction' of West German strategic culture
}

Interest politics alone ... cannot account for Germany's pacifistic military security policy, nor does it provide a satisfactory explanation of Bonn's approach to national sovereignty or its aversion to unilateralism. One must look beyond material and political interests to the politics of national identity in post war Germany, which unfolded in searing domestic political debates over rearmament, reunification, and European integration carried out under the watchful eyes of neighbouring countries and allies. ${ }^{1}$

As shown in the previous chapter, the identification of a strategic culture should proceed with the pinpointing of the formative period of its creation. The formative period in the emergence of the Federal Republic's strategic culture is arguably far easier to locate than that of other cases. It is the 'collective infancy' represented in the notion of 'zero hour' (Stunde Null) in 1945, which signified a strategic cultural discontinuity and social trauma so profound that 'affective and evaluative schemes had to be re-learnt' in the new West German State, including matters relating to the place of the armed forces within politics and society and the use of military force. ${ }^{2}$ This relearning was determined partly by domestic contextual factors and partly by international impositions and demands. Importantly, what was a critical moment in German history was turned by the architects of rearmament and by the creation of the Bundeswehr into a critical juncture for the wholesale construction of a fresh strategic culture.

The aim of this chapter is to draw out the antecedents of what came to be (West) German strategic culture and to identify the key debates and processes at work during its formative period. A detailed microstudy of the rearming of the Federal Republic is not needed here, as it has been more than adequately accomplished elsewhere. ${ }^{3}$ What is required, rather, is an account, through the lens of strategic culture, of 
the creation of the Bundeswehr, together with a fusion of the international and domestic contexts of West German rearmament. The chapter shows that the forging of a new strategic culture in West Germany occurred through two principal channels: the imposition of the will and demands of the allies as to what kind of role the Federal Republic should play; and post-war domestic conditions in West Germany. Thus the emergent strategic culture was a result of what was externally demanded and what was internally offered. Essentially this configuration excluded certain options while necessitating the inclusion of others.

\section{The context: Stunde Null}

Stunde Null implies the total physical, moral and psychological devastation and trauma that prevailed in Germany at the close of the Second World War. The wake of Stunde Null brought with it a forced rethink of conceptions of identity, power and nationhood, since previous definitions had proved profoundly disastrous for both Germany and the international community. Although the very notion of Stunde Null is contested, it is argued here that, in the field of security policy and the organisation of the armed forces, the term accurately conveys the clear break with the past that prevailed after the Second World War and on which new policies and practices were constructed. One of the most obvious manifestations of Stunde Null was the central importance accorded to political rather than strictly military ideas in shaping the process of rearmament and the creation of the new armed forces. Bork and Gress speak of Stunde Null as a 'basic emotion', central to which was 'a scepticism, indeed a rejection of all things military, contempt for the older generation and a broad rejection of political ideology'. ${ }^{4}$ To understand the meaning of something that has been called a basic emotion, although not easy, is vital in understanding the domestic context of West German rearmament. To fully understand and, more importantly, to see how it impacted on and influenced the rearming of West Germany, Stunde Null's constituent parts must be unpacked and disaggregated into exogenous and endogenous factors.

\section{Exogenous factors}

The exogenous factors of Stunde Null imposed on Germany comprehensive and wide-reaching preventative measures to rid it of the 
capacity, potential and will to either fight another war or raise armed forces. This was a fundamental part of the larger debellation of West Germany after the Second World War. In the blueprint for Germany's unconditional surrender the allies spoke of their determination to destroy German militarism and Nazism. In pursuit of these aims and in the design of their rule over occupied Germany the allies declared that it was not their intention to destroy or enslave the Germans, but rather to give them the opportunity to prepare for the reconstruction of their lives on a democratic and peaceful basis. The subsequent political principles laid out by the allies for the government and treatment of Germany in the initial control period embraced the complete 'disarmament and demilitarisation of Germany and the elimination or control of all German industry that could be used for military production'. In realising this,

all German land, naval and air forces, the S.S., S.A., S.D. and Gestapo, with all their organizations, staffs and institutions, including the General Staff, the Officers' Corps, Reserve Corps, military schools, war veterans' organizations and all other military and quasi-military organizations, together with all clubs and associations which serve to keep alive the military tradition in Germany, shall be completely and finally abolished in such manner as permanently to prevent the revival or reorganization of German militarism and nazism. ${ }^{5}$

These aspects of allied policy towards Germany amounted to a 'military emasculation', aimed at destroying the roots of German militarism, viewed by the allies as residing predominantly in the general staff and the officer corps.

\section{Endogenous factors}

It is important to note that the allied policies of demilitarisation were viewed largely as legitimate by West German society, a significant difference from the situation after the First World War when allied punishment and reparation were deemed 'unjust', thus helping nurture the continuance of the German general staff and its political role. This time the obliteration of Germany's sources of military power was neither publicly disputed nor resented, being instead accepted by and made the official policy of the new Federal Government. As von Friedeburg noted, in the construction of West Germany's new identity and international rehabilitation, its peaceful economic and social reconstruction, military forces seemed totally irreconcilable. ${ }^{6}$ 
Stunde Null brought with it an exhaustion of nationalism, in the form of a disavowal of Germany's militaristic past. The profound effects on German society of defeat in what had been an abnormal war resulted in the feeling of 'Never again'. This widespread determination to never again allow the military to play a central role in the destiny of the nation or to see military power play a defining role in foreign policy necessarily disposed a large sector of society to actively resist the rearming of West Germany. This public feeling was manifest in the idea of Ohne Mich, or 'count me out', a broadly based movement which came to characterise domestic reticence about and opposition to military issues. A further crucial aspect of Stunde Null was the defamation of the soldier, as seen in the collapse of the respect and prestige attaching to the vocation of the soldier and delegitimising of military values and traditions.

The manifestations of these external and internal aspects of Stunde Null were apparent in the Basic Law, which, in its initial conception, did not plan or make provisions for future armed forces. At its inception, the Federal Republic was a state without an army. It was not until the processes of rearmament were concluded that a mass of security and military-related laws were incorporated into the Basic Law in March 1956. What was present in the constitution in 1949 was a three-tiered construction of checks and balances, directly relating to the past, which together remained the cornerstones of the Federal Republic's security policies. This triad of constitutional clauses was constituted by:

- article 26, which sees as unconstitutional '[a]cts tending and undertaken with the intent to disturb the peaceful relation between nations, especially to prepare for aggressive war';

- article 24, which permits the Federal Republic to enter a system of mutual collective security; and

- article 4, which declared: 'No one may be compelled against his conscience to render war service involving the use of arms.'

In both its exogenous and endogenous manifestations, the effects of Stunde Null were diametrically opposed to the rearming, in whatever way, of the fledging Federal Republic. However, the imperatives of rearmament rapidly accelerated and, together with Konrad Adenauer's disposition towards the regaining of sovereignty through alliance with the West, the task in hand became not so much if or when rearmament would occur, but how. 


\section{The rising imperatives of rearmament: 'the requirements'}

... like undertakers performing an amputation on a corpse. For five years we have been blowing up bunkers, cutting holes in air raid shelters, dismantling factories, silting harbours, banning the production of toy soldiers and pop-guns and re-orienting the German mind. Having stripped Germany of every possibility of defense, the irony of the sudden appeal to the Germans to get in there and defend what we believe in is obvious. It is like mentioning a rope in the home of somebody who has been hanged. ${ }^{?}$

The imperative of realising West German rearmament was from the very outset conceived of within a broader Euro-Atlantic setting. Even prior to Adenauer's initial offers of a West German defence contribution and the subsequent deliberations over the European Defence Community (EDC) and then NATO membership, it was clear to many that rearmament was inevitable and the imperative was to make sure that West Germany was on the 'right side'. With the exacerbation of East-West tensions in late 1947, US planners remained faced with the most alarming forecasts of potential conflict in Europe based on the operation plan 'Offtackle'. Premissed on this plan, almost all of Western Germany would be 'occupied even in the best case scenario', and Western Europe as a whole would have trouble holding a defensive line at the Pyrenees. With the profound dearth of manpower in Central Europe, the logical remedy, in the view of the US and the UK, was the rearmament of West Germany. In this context, a West German contribution was deemed an essential anchor in the West's security, as a means of sharing the defence burden and of resisting emerging tendencies to create a neutralised zone in the heart of Europe. In West Germany, although the reappearance of uniformed Germans was still largely an illegitimate idea, the Christian Democratic leadership was predisposed to meet British and American interests in order to secure its own objectives, namely the acquisition of sovereignty, international rehabilitation as an equal through integration with the West, as well as solid allied security guarantees. In essence, the raising of a West German defence contribution was to be the 'epoxy', or glue, that bonded a mutually advantageous set of policies. 


\section{Internal discord: an armed force for what?}

The real intensity and the nature of the Soviet threat, its bearing on the security of the Federal Republic and what would be the best means of dealing with it were issues of dispute in the party politics of the new West German State. Party-political discord over rearmament revealed the innate differences between the Christian Democratic Party (CDU) and the Social Democratic Party (SPD) on their perception of the form that West German grand strategy should take and the best means to prioritise and realise national unity. For those reasons it is worth sketching out the principal differences between these positions before moving on to outline the ideas that won through.

Adenauer's approach to the rearming of West Germany must be understood in the context of his Politik der Stärke ('policy of strength'), but this was tempered by his conviction that West German rearmament was to be avoided unless absolutely necessary. In an interview in the Cleveland Plain Dealer on 3 December 1949, Adenauer reaffirmed his position that the rearming of the Federal Republic could be considered only if 'there was no way out', ${ }^{8}$ and was then plausible only in the context of a European army, with a German contingent under European command, since for Adenauer 'neutralisation, non-alignment, no alliances, were sordid words'.

In the wake of the interview, Adenauer's conception of rearmament gained greater clarity. Three interrelated factors determined his attitude:

- the acquisition of sovereignty as a consequence of rearmament;

- security against the rearmament of the Eastern Zone by Soviet Russia;

- the establishing of a European Federation entry into NATO.

From this point onwards Adenauer became less ambiguous about his desire to actualise a West German defence contribution. Again, what he was never ambiguous about was his conviction that West German rearmament could occur only in the context of a broader West European framework, and that a West German armed force would have anything but an exclusively defensive function.

With the outbreak of war in Korea in June 1950, which Adenauer likened to West Germany's geopolitical situation, he was able to put more boldly the offer of a West German contribution to the defence of Western Europe, together with demands to end the occupation of the Federal Republic as a quid pro quo. On 29 August 1950 Adenauer 
presented two memoranda to the Allied High Commission: one on the security of the Federal area, internally and externally; and another on questions relating to new structures for the occupation of the Federal Republic. The first outlined developments in the GDR, the creation of the Kasernierten Volkspolizei (KVP) and spoke of some kind of Federal police force to guard against internal subversion, at the same time calling on the allies to strengthen their own forces in the region; while the second made it clear that a defence contribution could be made only by a sovereign Federal Republic. Crucially for Adenauer, a less than sovereign West Germany under less than equal terms of allied tutelage would not be enough; moreover, continued occupation, in any shape or form, and the mere illusion of sovereignty might engender the type of anti-Western feeling prevalent in Germany after the First World War. In short, Adenauer saw that 'the rapid development of the army was the means to a political end, integration with the West'; and this close alliance with the West presented the Federal Republic with the only possible route to the ultimate goal of reunification. In 1950, when addressing the Bundestag on the issue of rearmament, Adenauer lucidly presented the situation as he saw it: 'the German defence contribution was necessary, the West wanted it, and the Germans owed it to civilization to produce it'. ${ }^{10}$

Adenauer's vision of rearmament, sovereignty and integration with the West was severely criticised by other voices and from the SPD. Strong anti-rearmament sentiments lay behind Gustav Heinemann's resignation from his position as minister for internal affairs in 1950. Heinemann's argument contrasted starkly with that of Adenauer, seeing that it was social rather than military rearmament that West Germany should move towards, which would thus enable the possibility of unification with the East and the construction of Germany as a neutralised zone.

Unsurprisingly, the opposition's first response was a blanket refusal to even consider the prospect of rearmament, and as debate proceeded on the issue the SPD's line of argument ran against that of the CDU on almost every count. It was the primacy of domestic politics, national unity and socio-economic reconstruction that guided the party's position on rearmament. Moreover, party leader Kurt Schumacher saw that such considerations should not be the business of the fledgling Federal Republic as was dictated by the occupation statute. ${ }^{11}$ In opposition to Adenauer's Politik der Stärke, the SPD at this time viewed rearmament as possibly squandering chances to realise national unity 
by exacerbating Cold War tensions. The route to national unity and international rehabilitation could be secured only by resisting the entanglement of the Federal Republic within Euro-Atlantic structures and, initially, by repelling rearmament, until social conditions were improved and a European political authority had been created. The SPD's position came to be increasingly at odds with the CDU's and was increasingly intransigent, being heavily flavoured by anti-militarism and the pursuit above all else of national unity. By the time that NATO membership for the Federal Republic had become a possibility, the SPD was declaring that should West Germany enter the alliance all chances for national unity would be dead.

Discord between the CDU and the SPD persisted on security questions even after the rearmament of West Germany had been sanctioned. As seen in the fierce Bundestag debates in early 1956 over the structure of the new armed forces, the issue of manpower mirrored the two parties' overall positions on the broader matter of rearmament. The SPD held the position that the Bundeswehr should be designed to balance the military presence in the GDR. Subsequently, for this task, a large standing force on the basis of universal conscription would not be necessary; indeed the return of conscription would compromise fundamental human rights and also require an amendment of the constitution. As the SPD conceived it, conscription would not be required to guard against the re-emergence of the armed forces as an isolated state within a state; moreover it would actively impede efforts at reunifying the two Germanies.

Meanwhile, in line with his strategy of equality and integration through rearmament, Adenauer favoured a large land-based force, and that necessitated the reintroduction of conscription. Without conscription, the argument ran, not only would the projected manpower structure of 500,000 men be unattainable, but the Bundeswehr would be unable to augment to around 1 million without a substantial reservist element ensured by conscription. This preference was bolstered, according to the CDU, by historical precedence, encapsulated in the belief that despite all attempts by politicians, professional armed forces in the Federal Republic would inevitably emerge as a dangerously isolated 'state within a state'. Conscription was viewed by the party also as commensurate with the new democratic ethos of West Germany.

It was Adenauer's ideas and the paradigm that 'size matters', the embedding of the FRG within Euro-Atlantic structures and the creation 
of a 500,000-strong Bundeswehr based on conscription, that ultimately won through. The law on compulsory military service was passed in July 1956, closely followed by the alternative Civic Service Act. This configuration served a couple of objectives: it firmly embedded the Federal Republic, as an equal, within the Western camp; and it awarded West Germany political capital and a degree of sovereignty.

\section{Institutionalising West German rearmament}

Concern over the rearming of West Germany and its institutional setting in line with US plans was apparent in the French 'Pleven plan', as announced on 24 October 1950. The Pleven plan's proposed Europeanising of the German problem through the creation of an EDC implied the dilution of West Germany's role. Aside from presidential ceremonial guards, there would be no independent West German forces; there would be a single European uniform, and command and control would be directed from a supranational level, with ultimate authority in the hands of a Board of Commission. This body would have extensive powers, embracing the range of functions normally fulfilled by national ministries of defence, the army, navy, air force, the treasury and the chiefs of staff. The Pleven option, which foresaw the dispersal of West German soldiers under non-German command, would mean singularisation for the Federal Republic, since the potential for West German input to decision-making was from the very outset low, with West German soldiers being automatically denied high-ranking positions.

Although Adenauer put his personal credibility behind the EDC project, and was hugely disappointed when it collapsed, he was also keen to realise the accession of the Federal Republic to the Atlantic Alliance as an equal member. As detailed earlier, for Adenauer, NATO membership always entailed as much political capital as it did military security for the Federal Republic, by awarding him diplomatic and political leverage. The rejection of the EDC treaties by the French National Assembly on 31 August 1954 was to enable this possibility. ${ }^{12}$

As noted above, even before the EDC option was dead and buried, Adenauer pursued the NATO and sovereignty option. According to Schwartz, Adenauer 'regarded unlimited sovereignty as just as important as NATO membership. ${ }^{13}$ Adenauer's preference for West Germany's NATO membership converged neatly with US and British designs. In London and Washington plans had already been drawn up on ways in which the Federal Republic's entry in to NATO could be 
realised. Soon after the French rejection of the EDC British diplomacy took forward the NATO option. The path eventually pursued was the 'European Solution', involving an extension of the 1948 Brussels Pact, which had made the Western Union into a Western European Union (WEU), incorporating both Italy and the Federal Republic. The WEU-NATO path paved the way for permanent British and American military contributions to continental Europe and also ensured West Germany's entry in to NATO with the right balance of control and manoeuvrability. ${ }^{14}$ Despite ongoing SPD objections and the attempted mobilisation of union protest, the Bundestag ratified the Paris treaties in February 1995 and the Federal Republic entered NATO in May of that year. Subsequent to this, the Parliament passed a bill enabling the Government to raise an army of 6,000 volunteers. In assuring the rearmament of the Federal Republic through membership in NATO, together with the acquisition of sovereignty, Adenauer proclaimed that 'we have reached the target we had set for ourselves very quickly'. ${ }^{15}$

\section{Designing a new armed forces: Soldat aus der Retorte}

Even before the rearmament debates really took off, thinking about the prospect of a rearmed West Germany and what the substance of a new armed forces might be had already begun in military circles in Germany. General Graf Kielmansegg, one of Adenauer's military advisors and a main protagonist in the internal design of the Bundeswehr, saw rearmament as 'inevitable' already in 1946. What Kielmansegg and other early thinkers had to assure was that West Germany was on the right side and also to measure the likely internal and external demands and constraints on a new armed forces. Although Adenauer had little empathy with the military as a whole, and with the officer corps in particular, he was acutely aware of the meaning and the political influence a substantial armed forces would bring to West Germany. Since, as detailed above, Adenauer was conscious of the inherent connection between armed forces and sovereignty and for Adenauer a state without armed forces was 'no state at all.'.6

Already, in 1948, Adenauer had begun to seek advice from former soldiers, most notably Generals Schwerin, Speidel and Heusinger, on the possibility of a future West German defence contribution. These former Wehrmacht senior officers and generals had respectable credentials and, importantly, shared Adenauer's vision of a new large West German 'post-national' armed force located firmly within the Western 
camp as an equal partner. Many of these discussions and plans were subsequently conducted within the frame of an embryonic defence ministry in the Dienstelle Blank, headed by Theodor Blank who had been assigned the position of 'Commissioner of the Chancellor for Questions Relating to the Augmentation of Allied Troops'. The accumulation of much of this early thinking and dialogue with ex-military officials was incorporated within the Himmeroder Denkschrift. ${ }^{17}$

\section{The Himmeroder Denkschrift}

Drafted in October 1950 and declassified in 1977, the Denkschrift represents the first systematic West German thinking on the design of a new armed forces. What comes across in the Denkschrift is an unyielding desire to fundamentally rethink the soldier's relationship to state and society, to deal with the past and to root any new military firmly within a post-national setting and the legal-constitutional framework of the emergent Federal Republic. In this sense the Denkschrift demonstrates that the draftees were intensely aware of the changed domestic and international contexts in which a new armed forces had to be conceived.

The three core aims of the meeting at Himmerod were to clarify:

- if, given the military and psychological prerequisites of the Western allies, a West German defence contribution could be made.

- how, in terms of organisation and command functions, a West German contingent could be realised in the context of a West European army; and

- in what form the build-up of West German troops could take place.

The contents of the Denkschrift echo Adenauer's motif of Politik der Stärke, seeing that the overcoming of Soviet aggression could be achieved only through the raising of military strength in Western Europe, including a sizeable West German contribution. The Denkschrift was also explicit in its identification of a Euro-Atlantic framework as the only context in which security for the Federal Republic could be attained as well as that within which any West German defence contribution should thus be realised. Further defining features of the Denkschrift included the necessity of identifying clear legal constraints on the new military in terms of limiting its role to Europe and also in terms of placing the armed forces under the jurisdiction of the Federal government and under the scrutiny of both the Bundestag 
and the Bundesrat. The Denkschrift also outlined the need to transform the relationship of the soldier to state and society, to which end a new Inneres Gefüge, or inner structure (the pre-cursor to Innere Führung, or moral leadership), was debated. The draftees were clearly mindful of the historical precedent and were adamant that any new German contingent should not become an isolated state within a state, subject only to its own rules and traditions. This time the individual soldier and the armed forces as a whole should be supportive and also equipped to enjoy democracy. To this end the Denkschrift spoke of the necessity of legally reducing the basic rights of the soldier only during the specific time of service and at the same time expanding to an unprecedented level the possibilities of democratic political participation for the soldier.

What is striking about this thinking is that the impetus came entirely from the Germans and, even more surprisingly perhaps, from the German military. Although Adenauer and other politicians had input to the design of civil-military relations and the armed forces' internal structure, it was really a major concern only for the military, who realised that success for the Federal Republic and its armed forces was clearly going to be dependent on a radical rethink of the role of the armed force, its position in society and its relationship to politics. The ideas proposed at Himmerod were deemed too revolutionary by the allies who wanted to reinstitute the German soldier of the Second World War whose courage, discipline and stamina they had come to know. This new thinking on internal structures, it seemed to the allies, could actually weaken a new West German armed forces. One of the chief proponents of the Bundeswehr's internal design noted that 'it took some time to convince [the allies of] what German military thinkers actually envisaged and to persuade them of the merits of a thorough reconstruction of civil-military relations'. ${ }^{18}$

\section{Constructing rearmament: 'the outcomes'}

The sections above presented the often opposing ideas as to if, how and in what form West German rearmament should proceed. The antecedents of the new West German strategic culture came from the fusion of an exogenously imposed will and set of demands, together with endogenous factors, namely the widespread anti-military sentiment present in West German society, together with efforts from sectors 
of the political elite to rehabilitate the Federal Republic as an equal in Euro-Atlantic institutions and to achieve sovereignty.

Although the broad institutional frameworks for West Germany's rearmament were in place by the mid 1950s it took some time to actually realise it. The Bundestag passed a bill in July 1955 for the raising of 6,000 volunteers and it took a further year to implement the Soldatengesetz. Furthermore, although the conscription bill was passed by Parliament in July 1956, it was not until the following April that the first conscripts were inducted. Such delays meant that rearmament fully in line with initial plans did not transpire until 1965, when twelve West German divisions were assigned to SACEUR (Supreme Allied Command Europe).

\section{Institutional frameworks: embedding West German security policy}

The institutional embedding of West German security policy was comprised of political, strategic and spatial elements.

As a direct reflex to the past, rearmament took place in a setting of multilateralism, entailing a break with a traditional military vocation, namely one based on purely nationally based decision-making and command and control structures. Under article 24 of the Basic Law, which allowed West Germany to 'enter a system of mutual collective security for the purpose of preserving peace', the founding of the Bundeswehr was a crucial step in the rehabilitation of West Germany through its membership in NATO and the WEU within the Western community. Thus the Federal Republic's security identity became a 'substitute identity', intimately bound up with the greater Western cause as demonstrated by its 'penetrated' security decision-making framework and the subordination of all West German troops to NATO's allied command. The removal of national central command structures was a prerequisite for the allied sanctioning of rearmament, given the anti-democratic nature of previous German general staffs. Instead command was provided by an 'integrated military commander' (eventually SACEUR), which acted as the 'guardian of German military interests'. ${ }^{19}$ The nullification of the German general staff was equally important as a prerequisite for domestic consent as recognised in the Himmeroder Denkschrift.

The Bundeswehr was conceived, legally activated and legitimised on the premiss that it was an armed force solely for the defence of West German territory and that of its NATO allies. This was based on a 
conflict scenario of the Warsaw Pact as aggressor and NATO as the framework for the Federal Republic's response. This scenario necessitated nuclear deterrence and forward defence, with the Bundeswehr to act as a 'trip-wire' geared to dissuade any potential aggressor from the threat or use of military force by virtue of its combat effectiveness and high level of operational readiness. In the words of a former Bundeswehr Generalinspekteur, the Bundeswehr had 'to be good enough to fight in order not to fight'. ${ }^{20}$

The political and strategic aspects outlined above translated into a legally stymied territorial role for the Bundeswehr. Since the Federal Republic's ability to raise forces and enter into a collective security system was restrained by the provisions of article $87 \mathrm{a}$, which saw that the Bundeswehr could be deployed only for defence purposes or for some other reason explicitly outlined in the Basic Law, the remit of the Bundeswehr was tightly defined as relating only to the territorial defence of the Federal Republic and its NATO allies. Such a remit precluded unilateralism and collapsed national interests into those of the alliance as a whole. Despite West Germany's entry in to the United Nations in 1973, this spatially restricted definition of the Bundeswehr's remit was further tightened by the Federal Security Council's later decision in 1982 which ruled against the legality of deployments 'out-of-area', thus confirming the limited territorial role of the Bundeswehr.

\section{Civil-military relations: at the heart of the matter}

The institutional frameworks outlined above defined the outer parameters for the creation of the Bundeswehr; these satisfied the demands and expectations of NATO allies by offering them a viable large fighting force totally wedded to and serving the alliance. Despite this clear institutional framework, which also furthered Adenauer's policy of 'strength and equality', patterns and practices of civil-military relations and the position of the soldier in both state and society also had to be reconceived if domestic complicity was to be assured. The success of the Bundeswehr in terms of acceptance and legitimacy at home would stem naturally from the degree of threat perception, but only if a resolute break with the 'unhealthy' civil-military relations that had previously existed was made.

This very difficult task, given that militaries tend to rely for their self-image and legitimacy on lengthy histories and traditions, could be achieved only through a range of balancing and checking measures, 
with the aim of creating a soldier who considered himself - and was considered by society - to be supportive of democracy. The new armed forces were not to be held above, forced below or allowed to perpetuate themselves within the new State, but were rather to coalesce with the Federal Republic via an extremely broad interface of civil-military relations. Unlike earlier incarnations of the German military, which had been either too weak or too strong, the Bundeswehr was to find equilibrium with state and society chartered through constitutional law.

As was emphasised at Himmerod, of paramount importance for future civil-military relations, societal acceptance and the viability of a new military was a satisfactory dealing with the past. An optimal balance of the past with a view to the future, meant the salvaging of the best and workable parts of the past, together with a thorough appraisal of the soldier's role in German history as well as the embracing of new ideas and formulas. Former Generalinspekteur Ulrich de Maizière describes the birth of the Bundeswehr as a 'new creation with a tradition', ${ }^{21}$ typifying the balance of old and new apparent in the forging of the Bundeswehr. Although the idea of Stunde Null is largely an accurate one for thinking about West German rearmament, and certainly the Bundeswehr did, to an extent 'enjoy' the grace of 'zero hour', it must be stressed that much of the past continued to play an important role in the design of the new armed forces.

In the years after Himmerod when the actual architecture of the Bundeswehr was being constructed, the difficulties of achieving an optimal balance of old and new became clear, given the exigencies of realising the Bundeswehr as soon as possible, the actual resources and manpower available, together with the doubts raised by the allies as to the desirability and feasibility of fundamental civil-military reform. ${ }^{22}$ Of prime importance was the requirement to enact the rehabilitation of the German soldier and to somehow desegregate his honour from the crimes of National Socialism. This was, to an extent, satisfied when both Adenauer and Eisenhower stated their personal recognition of the courageous endeavours of the German soldier and importantly made a distinction between the German soldier and the ideological servant of Hitler. ${ }^{23}$ This was crucial given that in terms of personnel, the Bundeswehr, up until the 1970s, largely had to rely on soldiers who had served in the Wehrmacht and the Reichswehr. The restoration of honour instilled a sense of worth and bolstered the self-image of the soldier, becoming an important factor in the formulation of a workable tradition for the Bundeswehr. Tradition for the Bundeswehr would have to 
present a de-glorification and a disrobing of German militarism of its pomp and ceremony. The military in the Federal Republic had to escape from its reactionary past and somehow become a 'mascot' of the new democracy; this, moreover, had to be achieved at a time when most of its leading manpower were former Wehrmacht soldiers and when even the basic credentials of the new State were still in a process of gestation by society at large.

In the formulation of a workable tradition for the Bundeswehr the best parts of the past were to be salvaged while the less workable aspects were to form a standard by which the future soldier could gauge the balance of conscience, rights and duties central to his vocation. Parts of military life prior to the Third Reich and, most importantly, the great Prussian reforms under Scharnhorst formed part of a workable past; but military history was to be read through ongoing criticism and continued scrutiny. At the core of the emergent tradition lay the plot against Hitler's life of 20 July 1944, symbolising the Bundeswehr's accent on honour through conscience rather than honour through obedience. Together with the centrality of the Basic Law, a dynamic sense of history was created for the Bundeswehr, bridging the old with the new.

\section{Reconceiving the soldier in state and society}

Reconceiving the soldier in the West German State and its society involved two interconnected issues: the legal embedding of the Bundeswehr within a functioning democracy; and the reordering of the military's Innere Ordnung (inner order).

The notion of Primat der Politik (primacy of politics) as the leitmotif for the embedding of the Bundeswehr within the democracy of the Federal Republic was manifest in a dense and multifaceted set of practices and institutions that served to anchor and navigate all aspects of security policy-making into constitutional law. The context of rearmament precluded from the very outset the creation of an armed force solely under the jurisdiction of martial law or solely subject to partisan politics. Instead, the dictates of Primat der Politik meant that the armed forces and security policies were situated firmly within the executive and surrounded by a dense web of civilian control. Crucially the Oberbefehl, or supreme command, resided in the hands of a civilian defence minister and consequently of the chancellor at times of crisis; while the highest-ranking soldier, the generalinspekteur, quite unlike the general staff of former times, was to act only as a military 'advisor' 
to his civilian superiors. Legislation on defence matters, including manpower structures and defence budgets, were securely a matter for the Bundestag and further enhanced by the Defence Committee. Augmenting the Primat der Politik were the functions of the Wehrbeauftragte, the parliamentary ombudsman for the armed forces, again empowered with extensive rights of access and scrutiny in assessing the correct implementation of Innere Führung in the Bundeswehr.

Also within the paradigm of Primat der Politik, adjudicating the balance of rights and duties in the life of the soldier was the new Soldatengesetz (Soldier's Law), which was essentially to ensure that democracy was not suspended in the military. The Soldatengesetz outlined the primacy of the soldier's identity as a citizen, with all the freedoms that this entailed, while at the same time it specified the essential constraints on the soldier, in accordance with his profession, that require a limitation of his full rights during, but only during, the period of service: 'Der Soldat hat die gleichen staatsbürgerlichen Rechte wie jeder andere Staatsbürger. Seine Rechte werden im Rahmen der Erfordnisse des militärischen Dienstes durch seine gestetzlich begründeten Pflichten beschränkt.' ${ }^{24}$

\section{Bürger in uniform and Innere Führung}

The leitmotif for the intellectual, political and moral reform of the military, were Innere Führung and Bürger in Uniform (citizen in uniform). The ideas of Innere Führung and Bürger in Uniform were direct reflexive responses to the past, aimed at instilling in the soldier a high level of 'thinking obedience' to guard against Befehl ist Befehl (orders are orders) being used as an excuse for atrocities, and to prevent the establishment of the military as a Fremdkörper (alien body) or a state within a state again, by bridging the chasm between the military and society that had characterised all previous German states.

Behind these notions, developed principally by Baudissin, lay the desire to fundamentally reorder the military's and the individual soldier's place in and relationship to state and society. For Baudissin in the age of total warfare and ideological conflict 'spiritual armament' was as important for the success of the Bundeswehr as were material capabilities. For the soldier to accomplish his mission he would have to be fully furnished with those freedoms and rights to the military defence of which he commits himself; he was to be 'given the feeling that he is a member of a free nation standing on the side of freedom'. ${ }^{25}$ 
Baudissin stressed the notion that 'German defence can be expressed only in the symbol of armed democracy' and that 'the potential which the German armed forces will add to European and Atlantic defence is closely connected with the extent to which the free way of life has meaning for Germans and the extent to which the German soldier identifies himself with it'. ${ }^{26}$

Put simply, Innere Führung is the programme and ethos for the internal order of the Bundeswehr and it is through adherence to the Basic Law and Innere Führung that the soldier as a Bürger in Uniform can be realised and maintained. Both notions are by definition dynamic in nature precluding, again as a direct reflex to the past, the emergence of the armed forces as a stolid, or worse, reactionary entity. Innere Führung, best understood as an 'anti-ideology', entails 'civics education and moral leadership', and is the tool through which the Basic Law gains meaning for the soldier by delineating both the possibilities and limits to his vocation, providing the link between values and standards in the Basic Law to leadership, education and training in the Bundeswehr. Innere Führung was aimed at ameliorating the tensions thrown up by the demands of military service and life as a full citizen; it ensures the operational readiness of the Bundeswehr on the one hand and the rights of the servicemen on the other. Through Innere Führung the old 'warrior' vocational model of the soldier was replaced by the representation of the soldier as more a 'technician', thus reducing the differences between the military and civilian society.

The Bürger in Uniform was the ideal and the reality which Innere Führung was to create. As already outlined, the Bürger in Uniform was to be a fully fledged member of society imbued with full rights of political participation and responsibility - to be circumscribed only by law and only for the duration of military service, the aim here in the basic architecture of the Bundeswehr being to dispose of the ideological caste of the military and to initiate the flourishing of a wide array of political and social ideas. This new political soldier, created with a view to the past and the dangers of both apolitical neutrality and overt politicisation of the military, was to engage fully with civilian politics in his right to vote and to stand for office.

Essentially, the Bundeswehr was to be as far as possible a mirror of society and was to be welded to that society through a broad interface of institutions and mechanisms. The place of the armed forces within society at large has continually been stressed: 'the federal armed 
forces, in so far as their tasks permit, take part in the intellectual, political and technical development of society'. ${ }^{27}$ Through its range of practices, the Bundeswehr was intended to be reactive rather than reactionary, inclusivist rather than exclusivist, and pluralistic rather than monistic, and capable of emulating the broader liberal democratic credentials of the Federal Republic. The accent, then, was on a broad civil-military relationship and one that was inherently porous.

\section{Conscription: a linchpin}

Wir sind dabei ein Werk der Demokratie zu schaffen. Die Wehrpflicht ist das legitime Kind der Demokratie. ${ }^{28}$

As indicated earlier in this chapter, the adoption of universal male conscription as a basis for the Bundeswehr went far beyond being an issue of mere manpower. Conscription was a linchpin, coordinating external and internal requirements for rearmament; fulfilling both strategic demands for a large armed force within NATO and domestic requirements for a democratically viable armed force. Vibrant party-political debates in the 1950s on manpower structures replicated and symbolised opposing political conceptions and priorities on national unity, the importance of the Western alliance, the nature of the Soviet threat and conceptions of national interests. To reiterate, conscription was seen as a prerequisite by the Government right from the start in its conception of a large land-based armed force firmly grounded as an equal partner within the Western alliance driven by the desirability of Bundnisfähigkeit (alliance credibility). ${ }^{29}$ In contrast, the opposition's design for rearmament envisaged a far smaller armed force with the expressed aim of balancing the military of the GDR. ${ }^{30}$

The conception of the Bundeswehr that won through was, as outlined earlier, premissed on Adenauer's paradigm of 'size and strength'. This necessitated the introduction of military service since such a large armed forces could not be achieved through volunteers alone, especially considering the desired augmented crisis strength of over 1 million soldiers. Thus compulsory universal conscription for a period of twelve months was introduced in September 1956. Conscription was further legitimised by the Government on the grounds that it was a manifestation of the democratic credentials of the new armed forces. It was elected as the best means to preclude the Bundeswehr's isolation from society, to ensure the congruence of military and societal 
values, and to guard against the emergence of the military as a state within a state. As Theodor Blank argued, conscription would be vital in ensuring the democratic integrity of the armed forces:

Ein Berufsheer steht immer in der Gefahr, ein 'Staat im Staate' zu werden. Das militärische Eigenleben, wenn es nicht durch den laufenden Zustrom von Wehrpflichtigen aufgelockert wird, kann trotz allen guten Willens der politischen und militärischen Führung und der parlamentarischen Kontrolle zu einer Isolierung der Soldatenführen Der unmittelbare Kontakt zum ganzen Volk, der allein die auch militärisch notwendige Eingliederung in die staatliche Gesamtordnung bewirkt, wird nur dann im wünschenswerten und notwendigen Ausmass vorhanden sein, wenn alle Männer verpflichtet sind, in dieser Armee zu dienen. ${ }^{31}$

Further justifying its position, the Government referred to the long tradition of conscription in Germany, placing the short and culpable existence of the Berufsheer as an interruption to this tradition. Conscription was placed as something almost natural to the German condition, while the professional armed force was the creation of an absolutist state; a reactionary or even 'depraved' type of armed force. This line of justification was drawn out by President Heuss in his famous dictum positioning conscription as the legitimate child of democracy, aiding and furthering the democratisation of the State by turning the defence burden in to a matter for all citizens. For Graf Baudissin and the other architects of the Bundeswehr too, conscription would be the means through which Innere Führung and Bürger in Uniform would gain real meaning and substance.

The SPD too was inclined to see the new armed forces as a break with German militarism, and it supported and provided input to the new internal order of the Bundeswehr and the practices of civil-military relations. However, conscription for the SPD, as already discussed, was neither strategically necessary nor a prerequisite for the democratisation of the Bundeswehr. Conscription, it was argued, was a totally reactionary idea and did not recognise the advent of the nuclear age in warfare; it would also impede the reunification of Germany by deepening its division. Furthermore, Fritz Erler challenged the notion that a professional armed forces endangered democracy and would necessarily develop into a state within a state. For Erler, the Geist of the whole military, whether a conscript or a professional force, would stem from leadership styles, rules and laws, rather than sources of manpower.

Conscription was introduced and legitimised as strategically necessary, but equally as the ultimate manifestation of the Federal Republic's 
Western democratic identity, ultimately becoming the 'clamp holding together the armed forces and society'. ${ }^{32}$

\section{Mapping West German strategic culture}

After identifying the key disputes, processes and solutions that prevailed during the formative period of West German strategic culture, it is now possible to map its contours and substance, in line with the framework developed in the previous chapter.

A first step is to record the ideas and policy options that were rejected or not even spoken of during this early formative period; this will confirm what West German strategic culture 'was not about'. Again in the case of the Federal Republic this is relatively easy to ascertain, since the space for manoeuvre available to West Germany at this time was narrow, given the constraints imposed on it by allied dictates, coupled with widespread domestic reticence and opposition to rearmament. Thus from the very outset the range of possibilities was slim. The following ideas and provisions have been drawn out as those which were excluded from the process of rearmament from the very outset:

- that Germany was neither answerable nor responsible for the damage inflicted by it during the war;

- a reticence to accept the imposition of the allied will or to resent it;

- the re-establishment of unilateral security and military policies;

- a striving to return as a leader in European security;

- the seeking of a security alliance with the Soviet sphere;

- rearmament and reinstallation of the role of the soldier without conditions;

- the re-establishment of armed forces outside of parliamentary scrutiny;

- that military force remained a viable tool of foreign policy in the pursuit of national interests;

- that citizens should be compelled to perform military service; and

- that the mobilisation of armed forces could be premissed on national sentiments.

Having identified what West German strategic culture was not about, 
it is now expedient to outline what is was about, in other words what was included from the very outset.

\section{Foundational elements}

Chapter 1 detailed the foundational elements which provide the deeper - basal - qualities, or fabric, of a strategic culture that have their origins in the primordial or formative phase of development. These foundational elements, which comprise basic beliefs and values regarding the use of force, give a strategic culture its core characteristics and are highly resilient to change; these tenets, or 'higher issues', refer to those values and beliefs that are to be secured, protected and promoted. The foundational elements of West German strategic culture are identified as follows.

First, there is historical rupture. 'Zero hour' (Stunde Null) is positioned as a defining point which negates much of previous German history, especially recent history which is regarded as the 'domain of shame and guilt'; ${ }^{33}$ these psychological aspects became a crucial ingredient in German security policy after 1945. Second, the use of force is no longer regarded as a justifiable tool of foreign and security policy, especially in the pursuit of national interests and twinned to this is the value assigned to the pursuit of stability and consensus-building. Third, the redundancy of militarism is evident in West German strategic culture: the military was no longer seen, by others or by itself, as the embodiment of national consciousness, identity and pride; moreover the vocation of the soldier was defamed and state and society was emasculated of all aspects of military culture. Fourth, an exhaustion of statism and nationalism prevailed: the nation state was rejected as the sole organising principle and referent of allegiance; indeed the State was seen as part of the problem and no longer the solution. This is manifested in the rupture with a 'traditional' military vocation, one based on national defence, grounded in realpolitik, enjoying sovereignty in policy-planning and policy-making.

\section{The linkage to policy preferences: security policy standpoints}

The foundational elements of strategic culture, as posited in chapter 1 , steer policy preferences by excluding certain options while including others; they delineate the range of legitimate options and lay out a finite repertoire of possible options for the policy-maker to pursue. This 
occurs through the emergence of security policy standpoints which act as intermediary factors, or 'transmitters', between foundational elements and regulatory practices. The intermediary security policy standpoints of West German strategic culture are:

- an aversion to singularity, unilateralism and leadership in security matters; a predilection to multilateral solutions and to conceive and promote interests through these;

- a predisposition to promote stability in the security sphere;

- a preference for non-confrontational defence and deterrence, and an opposition to war-fighting strategies, while emphasising the broader political role of armed forces;

- a general restraint on the use armed force, coupled with strong antimilitary sentiments;

- an aspiration both to pursue a responsible, calculable and accountable security policy, and wherever possible to 'make amends' for previous wrongdoings;

- a commitment to the full integration of the armed forces within civilian politics and society, exerting strong political control over the armed forces and embedding them within multilateral structures;

- a determination to pursue compromise and build consensus on both domestic and international security policy decision-making levels.

These standpoints translate further into active policy choices - the regulatory practices of West German strategic culture.

\section{Regulatory practices: governing premises and normative devices}

The regulatory practices of West German strategic culture are expressions of the foundational elements; they are observable manifestations, which are the policies and practices that actively relate and apply the substance of the strategic culture's core to the external environment. Regulatory practices are less resilient to change, and are split into two types: governing premises, the broader institutional boundaries that governed West German security policies since 1949; and normative devices, which apply specifically to the territory of civil-military relations.

West Germany's governing premises are expressed in

- the spatially stymied, legally defined, role of the Bundeswehr, foreclosing out-of-area deployments; 
- the embedding of West German armed forces within NATO command structures; and

- the strategic and legally sanctioned design of the Bundeswehr for defence-deterrence purposes.

The normative devices can be summarised thus:

- an ombudsman for the armed forces and a civilian defence minister ensure parliamentary control of the armed forces;

- a limited political role for the Bundeswehr generalinspekteur;

- Innere Führung and Bürger in Uniform; and

- conscription and conscientious objection.

\section{The cocoon of the Cold War}

Despite numerous challenges, shifts in the international sphere and developments in West German security policy in the decades after rearmament, the tenets of West Germany's strategic culture, as detailed above, persisted throughout the Cold War. This was due in no small part to the fact that a cross-party consensus emerged on key foreign and security questions, thus rendering West German strategic culture more robust and centripetal in nature. In the post-1950 period, especially from 1959 onwards, once the SPD had embraced EEC membership, earlier altercations over NATO and alliance strategy, as well as the issue of the Bundeswehr and its structure, tended to dissipate. This is not to say that challenges to existing modes and practices did not arise; but when they did West German elites chose policy options that were consonant with the existing strategic culture. Crucially, any attempts to question or fundamentally disagree with existing practices prompted debate and often fierce criticism. Among the numerous issues in respect of which West Germany's freshly constructed strategic culture served to steer policy options, the question of the Bundeswehr's remit and NATO's nuclear strategy in the 1980s stand out as examples.

Altercation over the Bundeswehr's remit surfaced when the Federal Republic became a member of the United Nations in 1973, a move which brought onto the agenda the issue of deploying soldiers for UN peace missions. Those in favour of West German involvement in this area argued that the Federal Republic's economic strength should lead 
to a greater willingness to contribute, militarily if needed, to global security. Although this idea went against the grain of West Germany's existing practices, proponents pointed to article 24 of the Basic Law which permitted Germany to 'enter a system of mutual collective security for the purpose of preserving peace'. Others, however, argued that West Germany's willingness here was constrained by article 87a, which stipulated that the Bundeswehr could be used only for defensive purposes. A consideration of this debate through the prism of strategic culture is instructive. It reveals a minor tension between two central tenets of West German strategic culture - that of 'reliable ally' and 'responsibility' in security matters on the one hand, and that of 'defence function only' on the other; and when calls came for greater West German participation it was the latter tenet that predominated. The out-of-area issue in its pre-1989 context seemed thus to confirm that the mainstay of strategic culture remained in place. In sum, prior to the ending of the Cold War no alternative strategy was pursued: the Bundeswehr's remit was not stretched beyond its original NATO 'inarea' defensive role, and, as the 1985 Defence White Paper saw it, 'the central mission of the Bundeswehr has not changed'.

As NATO strategy developed through the 1980s a chasm emerged between West German elite and broader societal perceptions in the face of what appeared to many to be the onset of a war-fighting strategy, epitomised in the proposed stationing of so-called 'Euro-missiles' on West German soil. In the face of widespread public dissent, the SPD-led Government stuck with a pro-alliance, pro-US, policy, sanctioning the deployments as a means to enhance security through deterrence and seeing no 'constructive alternative to the existing security policy'. ${ }^{34}$ This case seems similarly to reveal a number of points in relation to strategic culture - first and foremost, that Bonn's behaviour was again consistent with the postulates of strategic culture. Crucially, West Germany's position on the Euro-missiles sought to further the primacy of deterrence by bolstering its credibility and thus reducing the likelihood of nuclear war. Bonn's policy sought also to maintain the coupling, or affinity, of West European defence with that of the US. In essence, by following the US-led NATO line throughout the period, as well as pursuing a concomitant policy of seeking détente and arms' control, West German leaders were adhering to the core values of their strategic culture.

Throughout the period of the Cold War the foundational elements of West German strategic culture remained a self-reinforcing 'protected 
space', and their substance was not questioned. Historical rupture, the core from which policies subsequently emanated, remained in place and was not challenged: the notion steered policy choices, and when pre-1945 traditions and policy perspectives were advocated they were swiftly discarded in favour of post-1945 ideas and practices. This rupture is closely tied to the continued prevalence of anti-statism and anti-nationalism, and any move to revert to statist-nationalist perspectives was rebuked, with the articulation of a clear preference for and a commitment to continued multilateralism. Akin to this, the negation of unilateralism and avoidance of singularity reinforced West Germany's continued search for tight embeddedness, as an equal, within cohesive Euro-Atlantic structures. Furthermore, these institutional frameworks facilitated the articulation of a calculable, responsible policy style aimed at the promotion of stability. This enduring commitment to the furtherance of West Germany's tight institutional frame continued even during the era of Ostpolitik which, under Brandt, did not question the Federal Republic's membership of NATO and the EEC. A stolid repulsion of militarism also prevailed during this period, as seen in continued efforts to sustain and further West Germany's formula for civil-military relations. Anti-military sentiment endured as a visible facet of security policy, together with a manifest evasion of the use of force as a reflexive tool of security policy. Indeed, general restraint remained a defining characteristic of the Federal Republic's overall stance on security policy up until the ending of the Cold War.

How can these broad continuities and the persistence of strategic culture be explained? An answer is that the Cold War acted as a 'cocoon', actively precluding deviation from existing modes of thought and policy options. Bonn's Western allies were largely content with the Federal Republic's security policy profile. This was matched by West Germany's limited manoeuvrability as determined by the East. On the top of this, the West German leadership and the broader population were disposed to pursue a low-key set of policies, which was underpinned by a flourishing and stable socio-economic system, something that Germany had never previously enjoyed.

The question that flows from this concerns the effect of the ending of the Cold War on the existing strategic culture. More specifically, how did the events of 1989-90 and the demise of a relatively settled period influence Germany's strategic culture, now writ large on the newly unified state in the context of a less predictable and 'unsettled' period? This question is addressed in chapter 3. 


\section{Notes}

1 Peter J. Katzenstein (ed.) (1997) Tamed Power: Germany in Europe (Cornell University Press: Ithaca and London), p. 83.

2 Harry Eckstein (1988) 'A Culturalist Theory of Political Change', American Political Science Review, vol. 82, no. 3 (September), pp. 789-804, here p. 796.

3 See Gerhard Wettig (1967) Entmilitarisierung und Wiederbewaffnung in Deutschland 1948-1955 (Munich: R. Oldenbourg Verlag); Lutz Köllner, Klaus A. Maier, Wilhelm Meier-Dörnberg and Hans-Erich Volkmann (1990) Anfänge westdeutscher Sicherheitspolitik 1945-1956, Band 2: Herausgegeben vom Militärgeschichtlichen Forschungsamt (Munich: R. Oldenbourg Verlag); Hans-Gert Pöttering (1975) Adenauers Sicherheitspolitik 1955-63 (Düsseldorf: Droste Verlag GmbH); Donald Abenheim (1988) Reforging the Iron Cross: The Search for Tradition in the West German Armed Forces (Princeton, NJ: Princeton University Press); J. Montecue Lowry (1990) The Forge of West German Rearmament (New York: Peter Lang). Documentary analysis can be found in Karl D. Bredthauer (ed.) (1980) Dokumentation zur Wiederaufrüstung der Bundesrepublik (Köln: Pahl-Rugenstein Verlag).

4 Dennis L. Bork and David R. Gress (1989) A History of West Germany, Part 1: From Shadow to Substance 1945-1963 (Oxford: Blackwell), p. 45.

5 The Agreement on the Political and Economic Principles to Govern the Treatment of Germany in the Initial Control Period, A: Political Principles, 3.I.a.

6 Ludwig von Friedeburg (1968) 'Rearmament and Social Change', in Jacques van Doorn (ed.) Armed Forces and Society: Sociological Essays (The Hague and Paris: Mouton), p. 179.

7 James A. O'Donnell writing in Newsweek, quoted in Edwin Hartrich (1980) Fourth and Richest Reich: How the Germans Conquered the Post War World (New York: Macmillan), p. 60.

8 Konrad Adenauer (1966) Memoirs 1945-1953, English translation by Henry Regnery Company, Chicago (London: Weidenfeld \& Nicolson), p. 268.

9 Hans Peter Schwarz (1997) Konrad Adenauer: German Politician and Statesman in a Period of War, Revolution and Reconstruction 1952-1967 (Oxford: Berghahn), p. 138.

10 Bork and Gress (1989), p. 287.

11 William E. Paterson (1974) The SPD and European Integration (Westmead: Saxon House and Lexington, MA: Lexington Books), p. 72.

12 The EDC programme had changed substantially from the (French) Pleven Plan's conception of the project. In the original design West Germany's rearmament would have been 'contained and supervised' by the French, and the development of the EDC was, for the French, insufficiently restrictive on West Germany's military potential. 
13 Schwarz (1997), p. 113.

14 This required the removal of the occupying forces and the cancellation of the state of emergency clause in the German Treaty, as well as the voluntary self-limitation of personnel and equipment to the quotas as had been proposed in the EDC, including ABC weapons. The Paris treaties enabling the FRG's entry to NATO were almost unquestioned within the governing coalition, and in the final vote in the Bundestag the SPD was essentially out on a limb, with 320 votes against 150 .

15 Schwarz (1997), p. 125.

16 Ibid., p. 196.

17 The official title of this is Denkschrift über die Aufstellung eines deutschen Kontingents im Rahmen einer internationalen Streitmacht zur Verteidigung West-Europas (Working Paper on the Raising of a German Contingent in the Framework of an International Armed Force for the Defence of Western Europe). The Denkschrift was released for public use in 1977; it can be found in full in Hans-Jürgen Rautenberg and Norbert Wiggershaus (1977) Himmeroder Denkschrift vom Oktober 1950: Politische und Militärische Ueberlegungen fuer einen Beitrag der Bundesrepublik Deutschland zur Westeuropäischen Verteidigung Militargeschichtliches Forschungsamt (Karlruhe: G. Braun); hereafter, Himmeroder Denkschrift.

18 Interview with General Graf Kielmansegg, Bad Krozingen, Freiburg, April 1998.

19 Catherine M. Kelleher (1990) 'Fundamentals of German Security', in Stephen F. Szabo, The Bundeswehr and Western Security (Basingstoke and London: Macmillan), p. 24.

20 Interview with General de Maizière, Bonn, May 1998.

21 Ibid.

22 Interview with General Graf Kielmansegg, Bad Krozingen, Freiburg, May 1998.

23 Abenheim (1988), p. 96; Wettig (1967), p. 401.

24 'The soldier has the same citizenship rights as any other citizen. His rights are legally limited in the context of his military service’: Soldatengesetz, $\$ 6$.

25 Count Wolf Baudissin (1955) 'The New German Army', Foreign Affairs, vol. 34 , no. 1 (October), p. 2.

26 Ibid.

27 Regulation 10/1 of 1972 (ZDF), issued by the Ministry of Defence, on the principles of leadership in the armed forces; see chapter IV, 'Self-Image of the Soldier', article 222.

28 'We are in the process of creating a democracy. Conscription is the legitimate child of democracy': President Theodor Heuss speaking in 1949, quoted in H. J. Rautenberg (1987) 'Wehrpflicht und Wehrdienst im Wiederstreit', in H. Brühl and F. Vogel (eds) Wehrdienst aus Gewissengründen (Bonn: Herford), p. 35. 
29 Denkschrift der Bundesregierung, 'Warum brauchen wir die Wehrpflicht?' Veröffentlich durch das Presse- und Informationsamt der Bundesregierung (April 1956).

30 Despite opposition claims that the Paris treaties did not bind the Federal Republic to raising a large peace time armed force of 500,000 men, it was an emphasis on 'size' - thus requiring the introduction of military service - that came to be the route followed. The EDC treaty had prescribed conscription as the basis of its manpower; also all other NATO states at the time had conscription, and for this reason alone West Germany could not be different. Additionally, from the outset of its deliberations on the rearming of West Germany France saw that the only path for West Germany was conscription.

31 'There is always the danger that a professional armed force will evolve into a "state within a state". Without conscription and the constant flow of conscripts, which make the military less of an exclusive entity, armed forces may become isolated - despite the good intentions of military and political leaders and parliamentary control. Direct contact with the population at large, this alone is the agent of integration into the fabric of the State, which is also desirable from a military perspective too. This will exist only to the desirable and required extent if it is compulsory for all men to serve in the armed forces': Theodor Blank in BMVg Fü S1 5 (ed.) (1975) Entscheidungen (11) - Auszüge aus Debatten des Deutschen Bundestages und des Bundesrates uber die Wehrverfassung und die innere Ordnung der Bundeswehr 1955-56 (Bonn), sections 153-8.

32 B. Fleckenstein (1988) 'Federal Republic of Germany', in Charles C. Moskos and Frank R. Wood (eds) The Military: 'More Than Just a Job?' (Washington, DC: Pergamon-Brasseys), p. 188.

33 Ian Buruma (1995) Wages of Guilt: Memories of War in Germany and Japan (London: Vintage).

34 Speech by SPD Minister of Defence Hans Apel, 27 October 1982, to the 25th Commandeurtagung, Ingolstadt: Ministry of Defence press release, 27 October 1982. 